\title{
Hilar Glissonean Access in Laparoscopic Liver Resection
}

\author{
Akihiro Cho \\ Division of Gastroenterological Surgery, Chiba Cancer Center Hospital \\ Japan
}

\section{Introduction}

Laparoscopy for liver resection is a highly specialized field, as laparoscopic liver surgery presents severe technical difficulties. However, the recent rapid development of technological innovations, improvements in surgical skills and the accumulation of extensive experience by surgeons have improved the feasibility and safety of a laparoscopic approach for properly selected patients [1]. Since the first report of laparoscopic anatomical left lateral sectionectomy in 1996 [2], increasing numbers of laparoscopic anatomical liver resections have been reported [3-6]. However, laparoscopic anatomical resection has not been widely accepted because major technical difficulties remain, such as hilar dissection and pedicle control. During open anatomical liver resections, each Glissonean pedicle is often ligated and divided en bloc extrahepatically $[7,8]$. Using the same concept, we describe herein a novel technique by which each Glissonean pedicle can be easily and safely encircled and divided en bloc extrahepatically during laparoscopic anatomical liver resection.

\section{Surgical technique}

Laparoscopic encircling of the hepatoduodenal ligament is usually performed using an Endo Retract Maxi (Fig. 1) or Endo Mini-Retract (Covidien Japan, Tokyo, Japan) to be used as a tourniquet for complete interruption of blood inflow to the liver only if necessary [9].

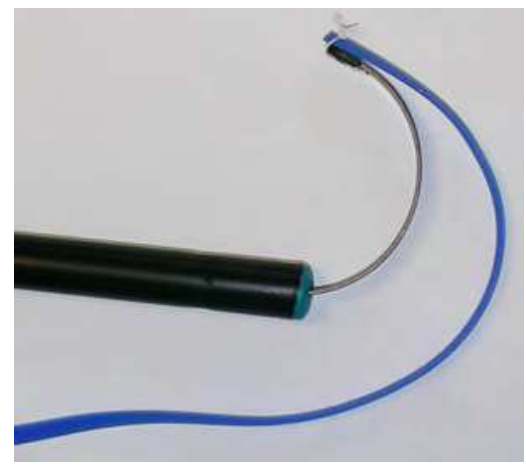

Fig. 1. Endo Retract Maxi in activated position. Vessel tape is preliminarily fixed to the tip of the metallic arch. 


\subsection{Encircling right-sided Glissonean pedicles, including the right, anterior, and posterior pedicles}

After dividing the cystic artery and duct and dissecting the gallbladder neck, the peritoneum of the hepatoduodenal ligament is dissected at the hepatic hilum (Fig. 2). Retracting the round ligament and gallbladder allows a good operative field of view, facilitating the encircling of each Glissonean pedicle. The metallic arch of an Endo Retract Maxi or Endo Mini-Retract is then meticulously extended between the hepatic parenchyma and the bifurcation of the right and left Glissonean pedicles, so the tip of the metallic arch is visualized (Fig. 3). Although the metallic arch is blindly deployed behind the Glissonean bifurcation, the tip can be safely delivered into the dorsal side of the hepatoduodenal ligament because the blade is blunt. The right Glisonean pedicle is encircled extrahepatically (Fig. 4). In the same way, the metallic arch of Endo Mini-Retract is meticulously extended between the hepatic parenchyma and the bifurcation of the anterior and posterior Glissonean pedicles, then the anterior or posterior Glisonean pedicle is extrahepatically encircled (Fig. 5) [10, 11]. Hepatic parenchymal dissection along the Cantle line facilitates inserting an endocopic stapler and dividing the right anterior and posterior Glissonean pedicles respectively (Fig. 6).

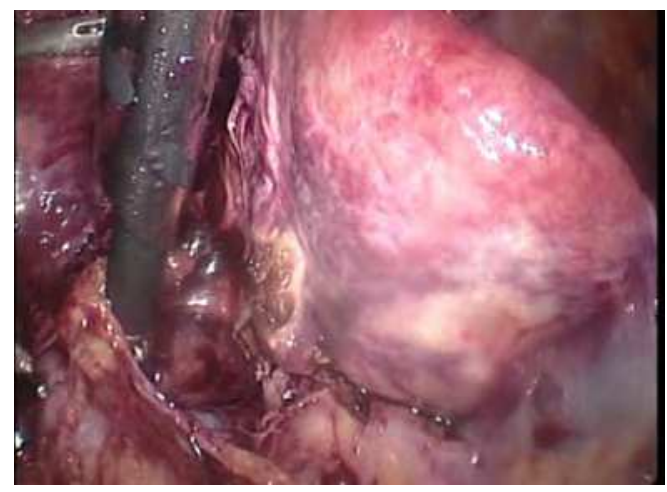

A

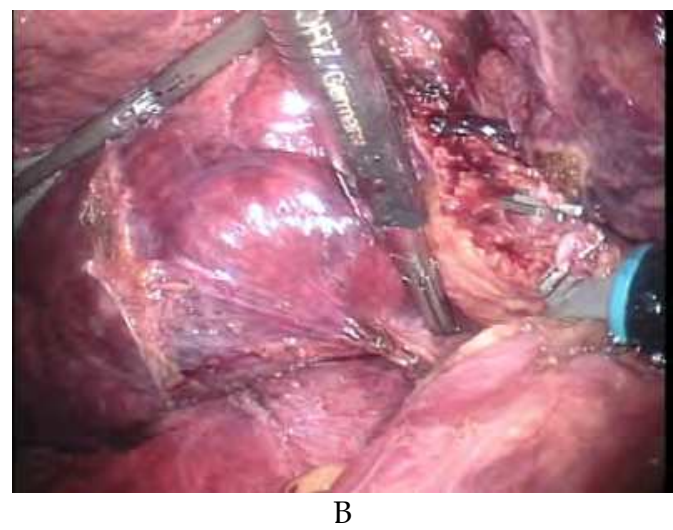

Fig. 2. Dissection between the hepatic parenchyma and the Glissonean bifurcation is performed from the ventral side (A) and dorsal side (B). 


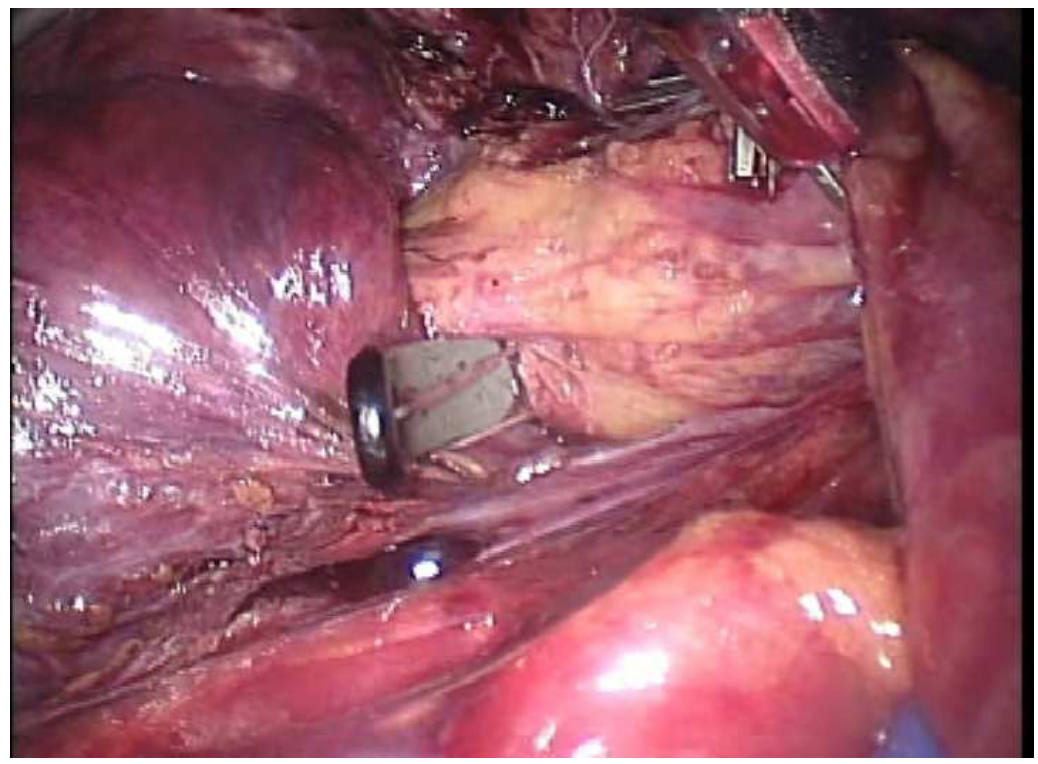

A

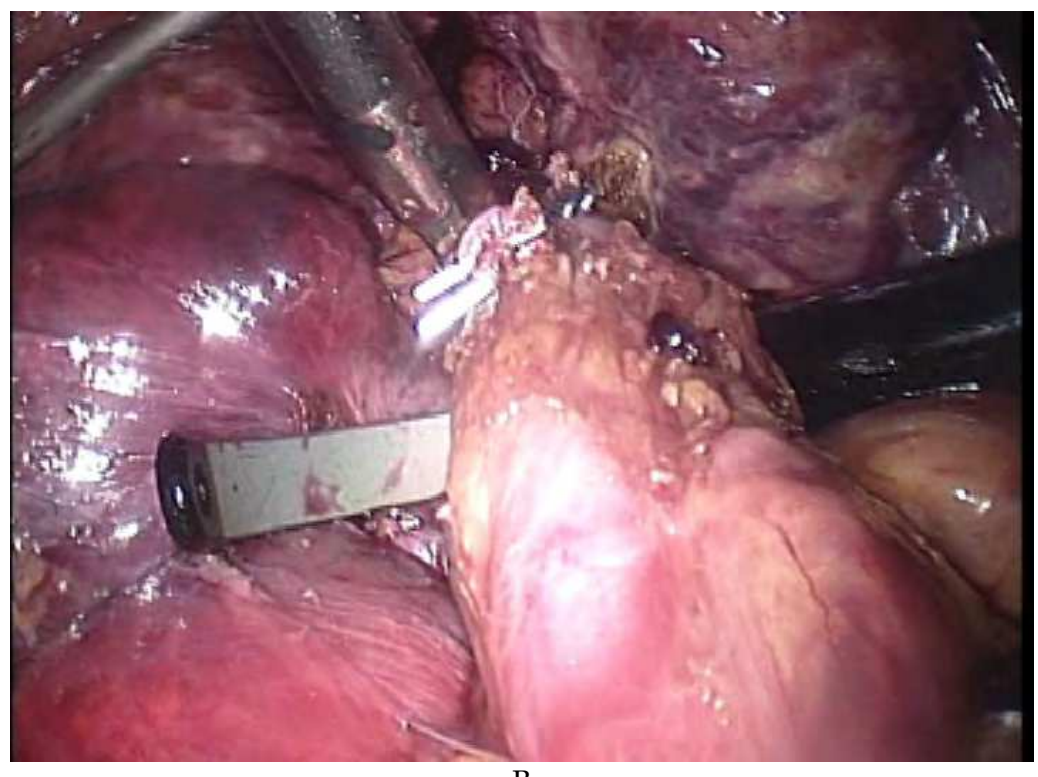

B

Fig. 3. An Endo Retract Maxi is introduced between the hepatic parenchyma and the bifurcation of the right and left Glissonean pedicles, so the tip of the metallic arch is visualized (A). The metallic arch is then meticulously extended (B). 


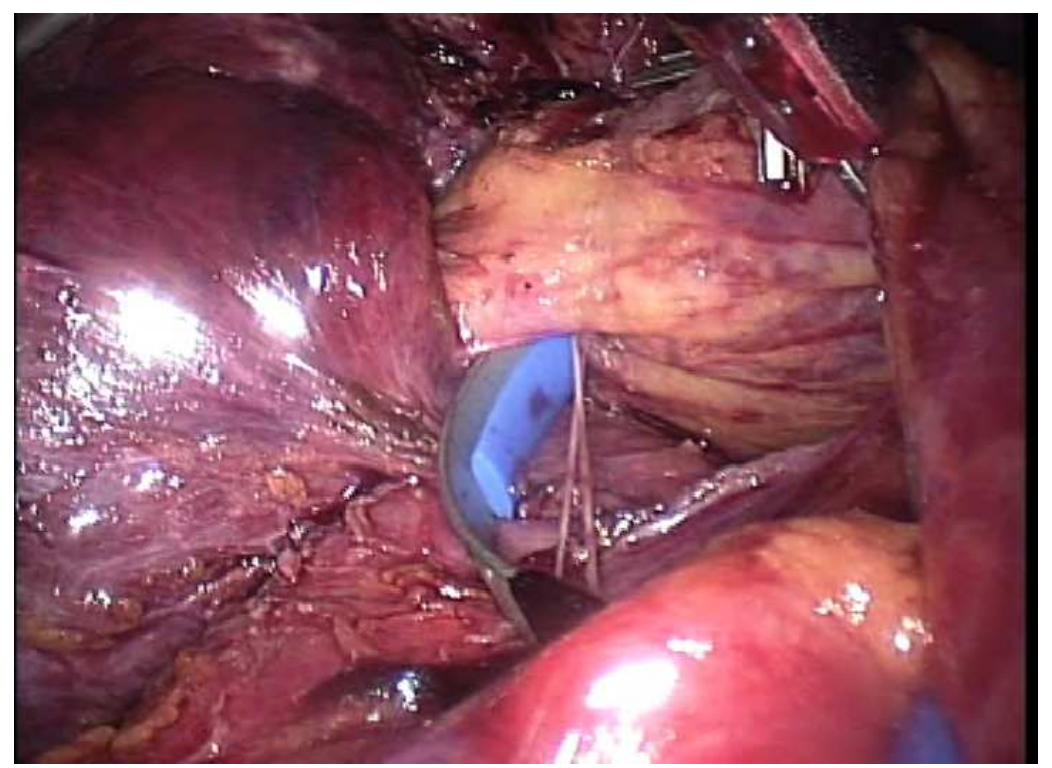

A

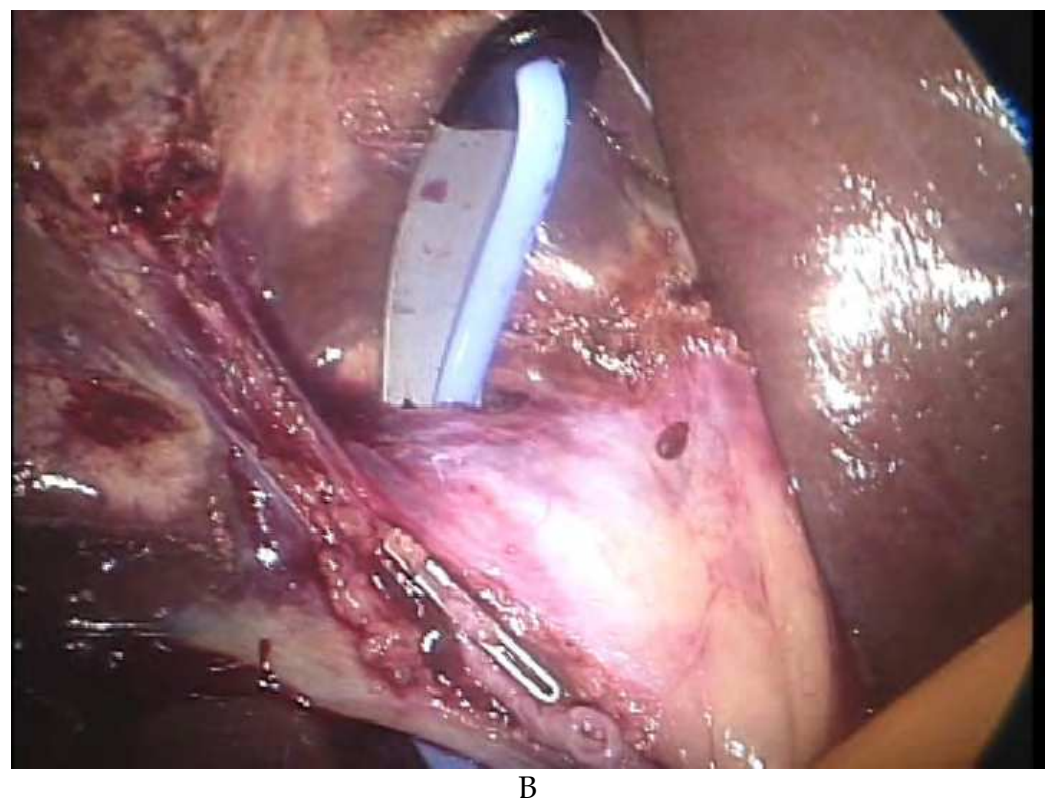

Fig. 4. The right Glissonean pedicle is encircled with an Endo Retract Maxi from the ventral side (A) and dorsal side (B). 


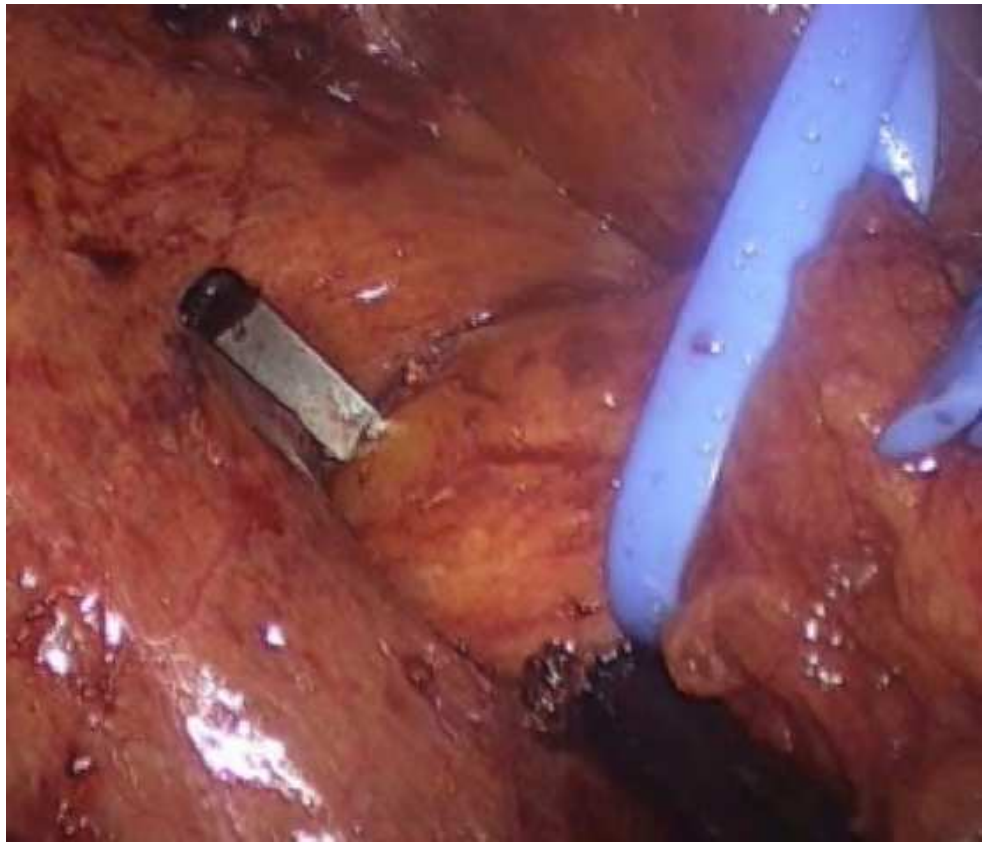

A

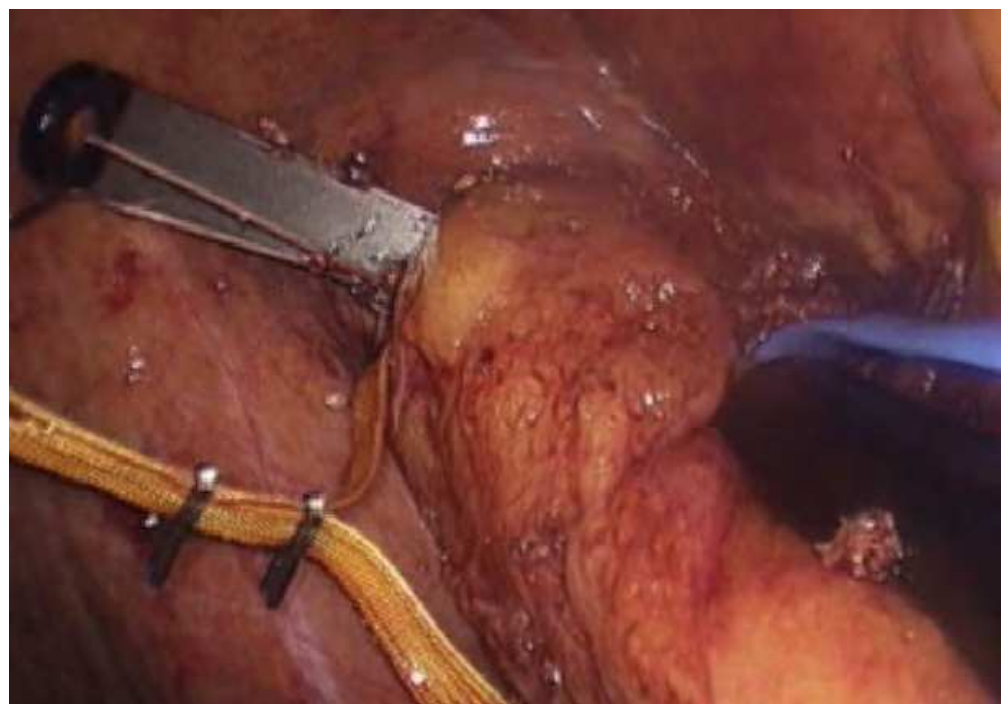

B

Fig. 5. The metallic arch of Endo Mini-Retract is extended between the hepatic parenchyma and the bifurcation of the anterior and posterior Glissonean pedicles, then the posterior (A) or anterior (B) Glisonean pedicle is extrahepatically encircled. 


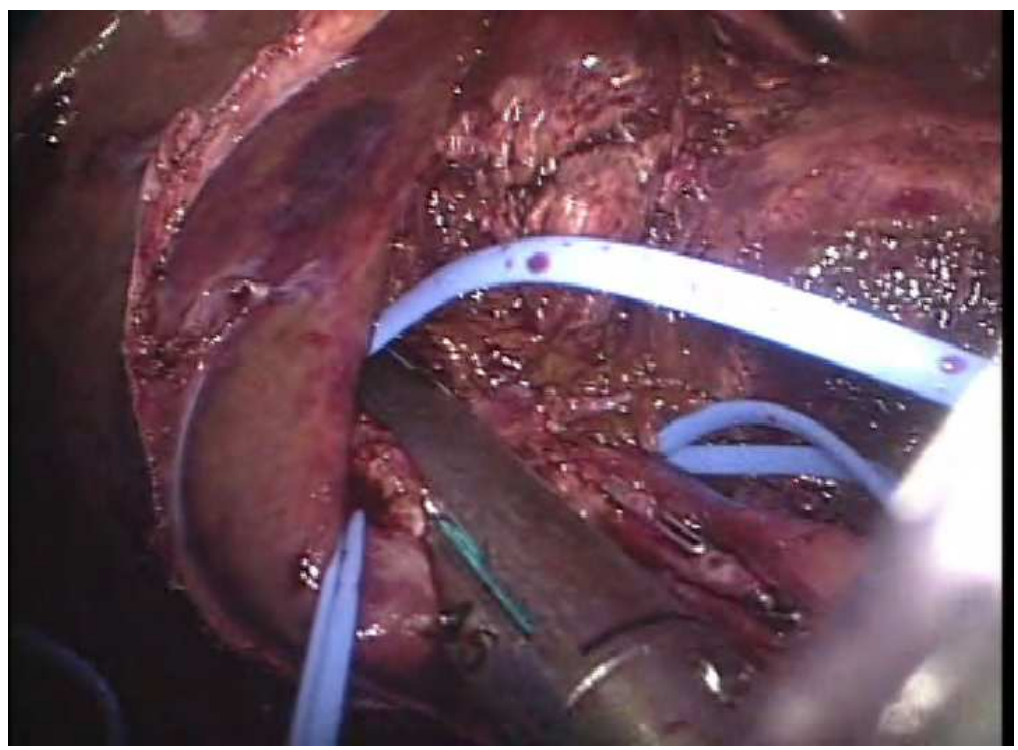

A

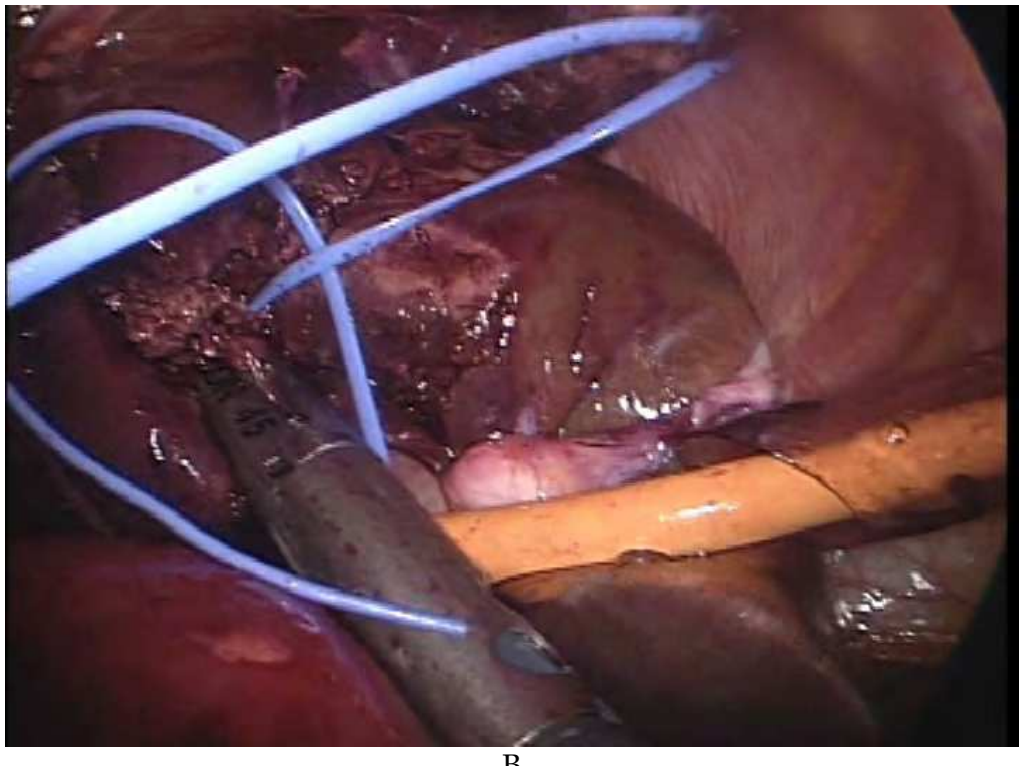

B

Fig. 6. The posterior (A) and anterior (B) Glisonean pedicles are divided respectively using an endocopic stapler. 


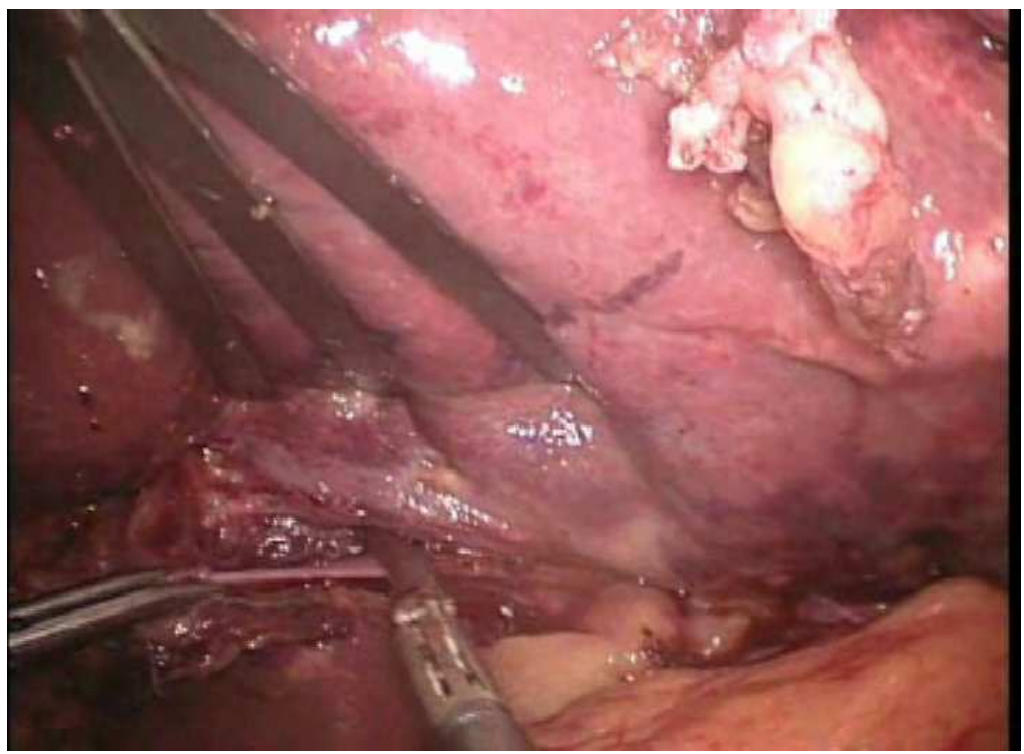

Fig. 7. The ligamentum venosum is divided.

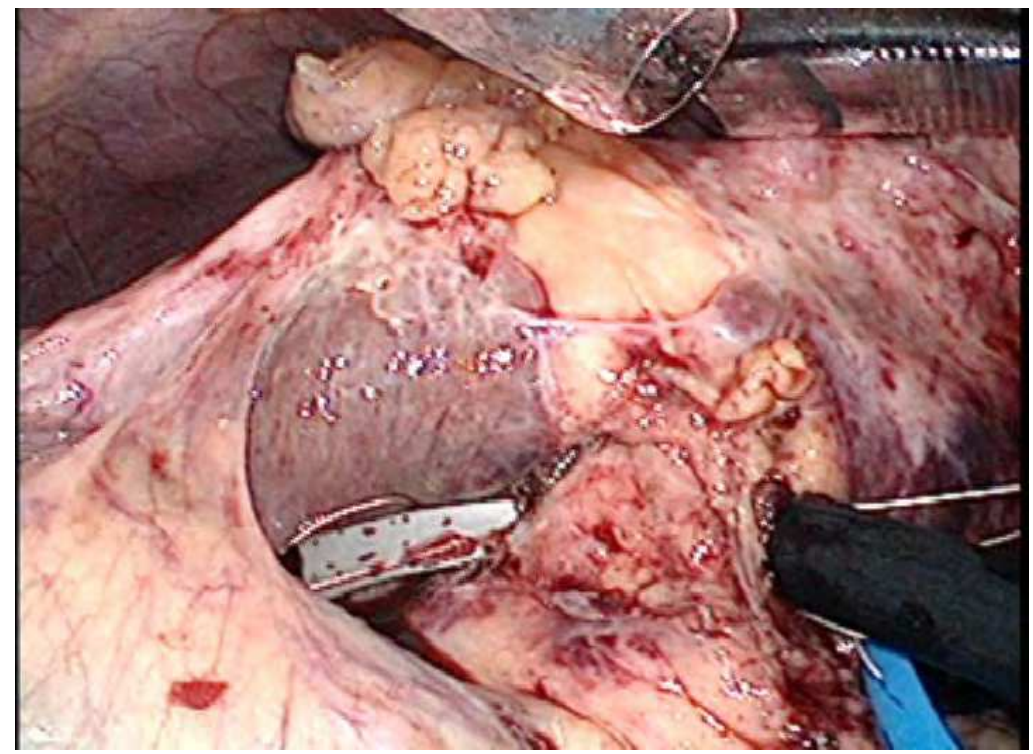

Fig. 8. The metallic arch of an Endo Retract Maxi is meticulously extended behind the umbilical plate, so the left Glisonean pedicle is encircled extrahepatically. 


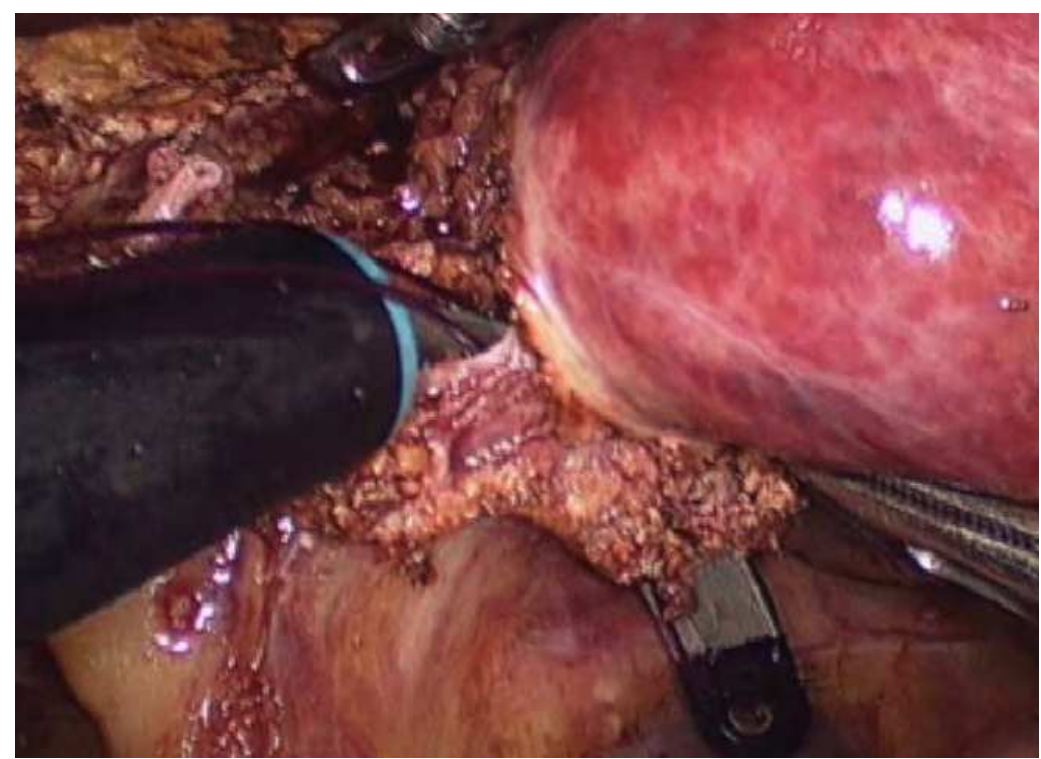

Fig. 9. The medial Glissonean pedicle is encircled with an Endo Mini Retract.

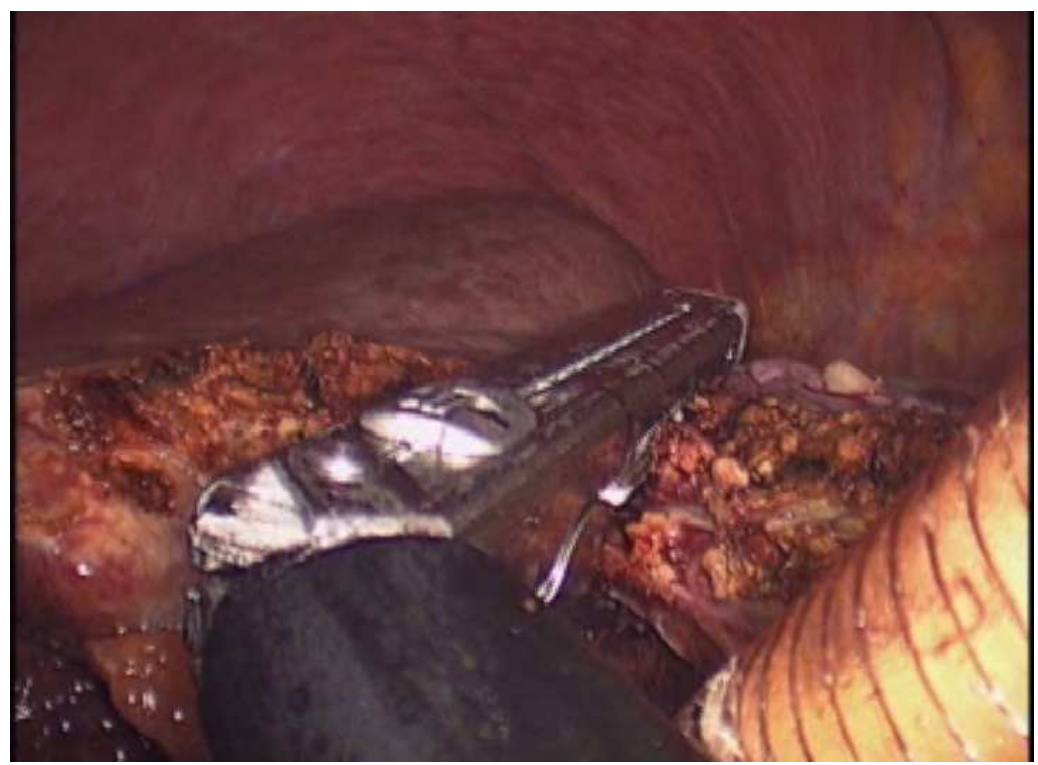

Fig. 10. The medial Glissonean pedicle is divided using an endocopic stapler. 


\subsection{Encircling left-sided Glissonean pedicles, including the left, medial, and lateral pedicles}

Dividing the ligamentum venosum (Fig. 7) and retracting the round ligament upward extends the umbilical portion, facilitating isolation of its root. A parenchymal bridge is divided if present. Dissection between the hepatic parenchyma and umbilical plate is performed. The metallic arch of an Endo Retract Maxi or Endo Mini-Retract is meticulously extended behind the umbilical plate, so the left Glisonean pedicle is encircled extrahepatically (Fig. 8). Hepatic parenchyma is divided along the main portal fissure, which facilitates dividing the left Glissonean pedicle using an endoscopic stapler. A little dissection of the hepatic parenchyma along the umbilical fissure facilitates isolation of the root of the medial Glissonean pedicle (G4) or lateral Glissonean pedicles (G2, G3). Dissection between the hepatic parenchyma and umbilical plate is performed, and G2, G3, or G4 is extrahepatically encircled using Endo Mini-Retract (Fig. 9) and divided using an endoscopic stapler based on resection type (Fig. 10).

\section{Comments}

Laparoscopic anatomical segmental resection has not been widely accepted due to technical difficulties in controlling each Glissonean pedicle laparoscopically. Previous reports relating to laparoscopic hemihepatectomy have described separate dissection and division of each of the hepatic artery, duct and portal vein [3-6], or an intrahepatic Glissonean approach [12, 13]. The entire length of primary branches of the Glissonean pedicle and the origin of secondary branches are located outside the liver and the trunks of the secondary and more peripheral branches run inside the liver [8]. Therefore, the right, left, anterior, posterior, medial, or lateral Glissonean pedicle can be encircled and divided en bloc extrahepatically. Using an Endo Retract Maxi or Endo Mini-Retract, an extrahepatic Glissonean approach can be safe and feasible. However, each Glissonean pedicles should be divided as distally as possible to avoid biliary injury. The right Glissonean pedicle should not be transacted en bloc but the right anterior and posterior Glissonean branches should be divided respectively. The left Glissonean pedicle should be divided at the root of the umbilical portion to avoid injury of the right hepatic duct. Therefore, the pedicle should be encircled left to the Spiegel branch. In addition, each pedicles show shorter extrahepatic courses, and thus are better divided after some amount of parenchymal dissection.

\section{References}

[1] Buell JF, Cherqui D, Geller DA, O'Rourke N, Iannitti D, Dagher I, Koffron AJ, Thomas M, Gayet B, Han HS, Wakabayashi G, Belli G, Kaneko H, Ker CG, Scatton O, Laurent A, Abdalla EK, Chaudhury P, Dutson E, Gamblin C, D'Angelica M, Nagorney D, Testa G, Labow D, Manas D, Poon RT, Nelson H, Martin R, Clary B, Pinson WC, Martinie J, Vauthey JN, Goldstein R, Roayaie S, Barlet D, Espat J, Abecassis M, Rees M, Fong Y, McMasters KM, Broelsch C, Busuttil R, Belghiti J, Strasberg S, Chari RS; World Consensus Conference on Laparoscopic Surgery: The international position on laparoscopic liver surgery: The Louisville Statement, 2008. Ann Surg 2009; 250: 825-380.

[2] Azagra JS, Goergen M, Gilbart E, Jacobs D: Laparoscopic anatomical (hepatic) left lateral segmentectomy-technical aspects. Surg Endosc.1996; 10: 758-761. 
[3] O’Rourke N, Fielding G: Laparoscopic right hepatectomy: surgical technique. J Gastrointest Surg2004; 8: 213-216.

[4] Dagher I, Di Giuro G, Lainas P, Franco D: Laparoscopic right hepatectomy with selective vascular exclusion. J Gastrointest Surg2009; 13: 148-149.

[5] Han HS, Cho JY, Yoon YS: Techniques for performing laparoscopic liver resection in various hepatic locations. J Hepatobiliary Pancreat Surg2009; 16: 427-432.

[6] Gayet B, Cavaliere D, Vibert E, Perniceni T, Levard H, Denet C, Christidis C, Blain A, Mal F: Totally laparoscopic right hepatectomy. Am J Surg2007; 194: 685-689.

[7] Takasaki K, Kobayashi S, Tanaka S, Saito A, Yamamoto M, Hanyu F: Highly anatomically systematized hepatic resection with Glissonean sheath code transection at the hepatic hilus. Int Surg1990; 75: 73-77.

[8] Takasaki K: Glissonean pedicle transection method for hepatic resection: a new concept of liver segmentation. J Hepatobiliary Pancreat Surg1998; 5: 286-291.

[9] Cho A, Yamamoto H, Nagata M, Takiguchi N, Shimada H, Kainuma O, Souda H, Gunji H, Miyazaki A, Ikeda A, Matsumoto I: Safe and feasible inflow occlusion in laparoscopic liver resection. Surg Endosc2009; 23: 906-908.

[10] Cho A, Asano T, Yamamoto H, Nagata M, Takiguchi N, Kainuma O, Souda H, Gunji H, Miyazaki A, Nojima H, Ikeda A, Matsumoto I, Ryu M, Makino H, Okazumi S: Laparoscopy-assisted hepatic lobectomy using hilar Glissonean pedicle transection. Surg Endosc2007; 21: 1466-1468.

[11] Cho A, Yamamoto H, Kainuma O, Souda H, Ikeda A, Takiguchi N, Nagata M: Safe and feasible extrahepatic Glissonean access in laparoscopic anatomical liver resection. Surg Endosc2011; 25: 1333-1336.

[12] Machado MA, Makdissi FF, Galvão FH, Machado MC: Intrahepatic Glissonian approach for laparoscopic right segmental liver resections. Am J Surg 2008; 196: 3842.

[13] Topal B, Aerts R, Penninckx F: Laparoscopic intrahepatic Glissonian approach for right hepatectomy is safe, simple, and reproducible. Surg Endosc 2007; 21: 2111. 


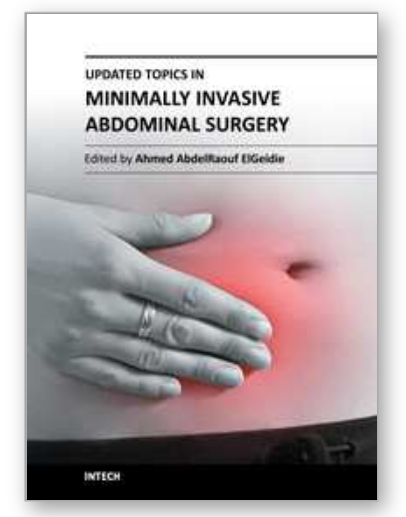

\author{
Updated Topics in Minimally Invasive Abdominal Surgery \\ Edited by Prof. Ahmed Elgeidie
}

ISBN 978-953-307-773-4

Hard cover, 246 pages

Publisher InTech

Published online 14, November, 2011

Published in print edition November, 2011

Updated topics in minimally invasive abdominal surgery provides surgeons interested in minimally invasive abdominal surgery with the most recent techniques and discussions in laparoscopic surgery. This book includes different topics covering a big variety of medical conditions with up-to-date information. It discusses many controversies in a clear and user-friendly manner. This book is made for young junior surgeons in training and also senior surgeons who need to know the most recent work in the field of laparoscopy. To make the material easily digestive, we provided the book with many figures and illustrations for different procedures and technical pearls.

\title{
How to reference
}

In order to correctly reference this scholarly work, feel free to copy and paste the following:

Akihiro Cho (2011). Hilar Glissonean Access in Laparoscopic Liver Resection, Updated Topics in Minimally Invasive Abdominal Surgery, Prof. Ahmed Elgeidie (Ed.), ISBN: 978-953-307-773-4, InTech, Available from: http://www.intechopen.com/books/updated-topics-in-minimally-invasive-abdominal-surgery/hilar-glissoneanaccess-in-laparoscopic-liver-resection

\section{INTECH}

open science | open minds

\section{InTech Europe}

University Campus STeP Ri Slavka Krautzeka 83/A 51000 Rijeka, Croatia Phone: +385 (51) 770447

Fax: +385 (51) 686166 www.intechopen.com

\section{InTech China}

Unit 405, Office Block, Hotel Equatorial Shanghai No.65, Yan An Road (West), Shanghai, 200040, China 中国上海市延安西路65号上海国际贵都大饭店办公楼405单元 Phone: +86-21-62489820

Fax: +86-21-62489821 
(C) 2011 The Author(s). Licensee IntechOpen. This is an open access article distributed under the terms of the Creative Commons Attribution 3.0 License, which permits unrestricted use, distribution, and reproduction in any medium, provided the original work is properly cited. 